\title{
ON THE EDGE OF CANTERBURY SETTLEMENT, 1854-58
}

PAUL STAR

\section{Abstract}

By reference to the 1850 s diaries of Thomas Potts, an early European settler in Canterbury, New Zealand, this article illustrates how farm diaries might be used to extend our understanding not only of environmental but also of rural history. Potts lived in Canterbury from 1854 until his death in 1888 and was a 'well bred' and wealthy runholder, politician, writer and naturalist. My interest in Potts has always centred on his curiosity about New Zealand's native species, his thoughts on how they were affected by European settlement, and his efforts to protect them. Today, however, I will be looking at other observations he made, and from a different perspective, using his diary. Potts kept a diary from 1854 to 1858 . He was then in his early 30 s and living in the vicinity of Windwhistle-aptly named-in inland Canterbury. He and his young family lived there initially at Valehead, then on Rakaia Terrace, both within easy walking distance of Rockwood, which was his father-in-law's cattle and sheep station.

Keywords: Thomas Potts, Rockwood Station, Canterbury New Zealand, farm diary, environmental history, rural history, Peter Holland, Tom Brooking

Tom Brooking supervised my $\mathrm{PhD}$ on the attitudes of early European settlers to the New Zealand environment. ${ }^{1}$ Then, like some others here, I got dragged into the 'Empires of Grass' project, which he and Eric Pawson led. ' Since those heady days, when many of us first thought of ourselves as 'environmental historians', I have retreated more and more into a simple existence on the Otago Peninsula. I can claim, in fact, to lead a 'rural' life.

\footnotetext{
1 Paul Star, 'From Acclimatisation to Preservation: Colonists and the Natural World in Southern New Zealand, 1860-1894' (PhD diss., University of Otago, 1997).

2 See Tom Brooking and Eric Pawson, eds, Seeds of Empire: The Environmental Transformation of New Zealand (London and New York: I. B. Taurus, 2011).
} 
Tom, meanwhile, has gone from strength to strength, writing his very fine biography of Richard Seddon, ${ }^{3}$ and now-supposedly in retirement-researching the making of rural New Zealand. I've never seen myself as a rural historian, but the present occasion ${ }^{4}$ encourages us all to bend our thoughts in this direction, and I'm pleased to have this chance.

My MA thesis was on 'T. H. Potts and the Origins of Conservation in New Zealand (1850-1890)'. ${ }^{5}$ I began work on this in 1990, and since then have published articles on New Zealand's changing environment in which Potts receives mention. Now, 30 years down the track, I finally have a book published about Potts. ${ }^{6}$ It includes reference to his first years in New Zealand, on the edge of Canterbury settlement. This article touches lightly on that edge, through the eyes of Potts and with regard to others who were there at the time.

Thomas Potts lived in Canterbury from 1854 until his death in 1888 and was a 'well bred' and wealthy runholder, politician, writer and naturalist. My interest in Potts has always centred on his curiosity about New Zealand's native species, his thoughts on how they were affected by European settlement, and his efforts to protect them. Today, however, I will be looking at other observations he made, and from a different perspective.

Potts kept a diary from 1854 to 1858 . He was then in his early 30s and living in the vicinity of Windwhistle-aptly named — in inland Canterbury. He and his young family lived there initially at Valehead, then on Rakaia Terrace, both within easy walking distance of Rockwood, which was his father-in-law's cattle and sheep station.

We are fortunate to also have 3 other diaries from the same location and from the same period or slightly later. First, there is the parallel Rockwood Station diary for 1855 to 1857 , mostly written by Potts' father-in-law, Henry Phillips. Second, as I only learnt quite recently, there is another Rockwood diary, written by Henry's son George, covering 1863 to 1869 . Lastly, there is the diary for 1866 to 1871 , mostly written by another son, Tom, who was based at 'The Point', the station next to Rockwood. None of these diaries have been published, and the Potts and George Phillips diaries remain in private hands.

3 Tom Brooking, Richard Seddon: King of God's Own: The Life and Times of New Zealand's Longest-serving Prime Minister (Auckland: Penguin Books, 2014).

4 An earlier version of this paper was presented at the symposium 'Making Rural New Zealand: Environment, Economics and Politics', held at Dunedin in 2018 to mark the retirement of Prof. Tom Brooking of the University of Otago.

5 Paul Star, 'T. H. Potts and the Origins of Conservation in New Zealand, 1850-1890' (MA diss., University of Otago, 1991).

6 Paul Star, Thomas Potts of Canterbury: Colonist and Conservationist (Dunedin: Otago University Press, 2020). 
I think a close analysis of all these diaries, examined together, would be a great rural history project. Between them, in different ways and from different angles, they detail the beginning of one particular settlement, one example of rural New Zealand in the making.

I am also aware of 2 retrospective descriptions of the early homestead at Rockwood, which lay at the core of the Phillips' runs. Published in 1870 and 1882, both descriptions are sentimentalised, reflecting the rural ideal that their authors were brought up with in England.

First, Mary Anne, Lady Barker, described Rockwood as seen from above-from the hills that divided her husband's station from the Phillips'. 'Nothing', she said,

could be more effective than the white gable of the house standing out against the vast black birch forest which clothed the steep hill-side for miles- the contrast so picturesque between the little bit of civilization and culture and the great extent of wild, savage scenery around it. ${ }^{7}$

Second, Potts himself, in his old age, reminisced about Rockwood as he had known it 30 years before. He wrote of his father-in-law's house, 'nestling well up in a valley at the foot of a sombre beech-wood that covered rocky mountain slopes in the very heart of picturesque and romantic landscapes' ${ }^{8}$

These are identifications both of settlement and of setting, which have as much to do with what the mind imagined as with what the eye saw. They are valuable, for they display what rural settlement seemed to have been about.

Diaries that were written at the time, and for the most part without much reflection, show better what it was actually about. Later, I will touch on the idea of a changing vision of rural New Zealand running alongside a changing reality, but I will begin with the reality that is recorded, albeit selectively, in diaries.

The problem with nearly all station diaries is the brevity of their entries and the narrowness of their focus. Often, the things you most want to know about are the things they leave out. What you get is a basic record of changes in the weather, stock movements, gardening, farming and visitors. I looked at a few Southland farm diaries when working on 'Empires of Grass' and found they were hard nuts to crack. ${ }^{9}$

\footnotetext{
[Mary Anne,] Lady Barker, Station Life in New Zealand (London: Macmillan, 1870), 91.

T. H. Potts, 'With the gun now-and then', New Zealand Country Journal 6, no. 3 (May 1882): 235-42.

Paul Star, 'On Southland farm diaries', unpublished paper (June 2004).
} 
The first New Zealand scholar to try the 'diary approach' was the Canterbury geographer W. B. Johnston, in about 1960. He analysed the diaries (1874-1900) of one family who were carving a farm out of Taranaki bush land. ${ }^{10}$ He grouped the family's various daily agricultural activities and looked for changes in the ratio between these activities that might correlate with the process of environmental transformation.

But he found he had a problem with silences. In a revealing paragraph, he wrote:

The time devoted to livestock cannot be accurately measured as the daily task of milking cows is seldom indicated in the diaries ... These tasks were largely done before breakfast or before the main task of the morning, or following the main work for the afternoon. Moreover, the womenfolk and the youngsters frequently carried out these tasks. ${ }^{11}$

Johnston's database, in other words, didn't regularly describe either the principal farming activity (it being a dairy farm) or the activity of over half of the labour force (it being a family farm).

Peter Holland and Ray Hargreaves, in about 1990, had another go at farm diaries. They chose to study the Point diary, by Potts' brother-in-law, Tom Phillips, which I have already mentioned. They found it 'remarkable for the picture it conveys of personalities, places and activities in frontier society' and said it 'hints at the rapid transformation of inland Canterbury's rural landscapes'. ${ }^{12}$ Like Johnston before them, they put the activities described into different heaps, coming up with 5 broad categories.

The fifth category they called 'personal'. To some extent this reflected the nature of the diaries they worked on, but it also indicated that Holland and Hargreaves were prepared to consider more than just the agricultural activity that Johnston had analysed. This was explicit in the title of the article that resulted: 'The Trivial Round, The Common Task: Work and Leisure on a Canterbury Hill Country Run in the 1860s and 1870s'. They acknowledged that this fifth category was 'something of a catch-all, yet [they said] a seasonal pattern can be discerned in time spent in non-productive ways. ${ }^{13}$ On the basis of some of the information in this category, they discussed how gold fever and alcoholism may have affected the rural community around Windwhistle.

10 W. B. Johnston, 'Pioneering the bushland of lowland Taranaki: A case study', New Zealand Geographer 19, no. 1 (April 1961): 1-18.

11 Ibid., 11.

12 P. G. Holland and R. P. Hargreaves, 'The Trivial Round, The Common Task: Work and Leisure on a Canterbury

Hill Country Run in the 1860s and 1870s', New Zealand Geographer 47, no. 1 (1991): 19-25.

13 Ibid., 23. 
This is the kind of thing that I would call 'social history', which must surely be an important component of any comprehensive 'rural history'. I am struck by Katie Cooper's notion of 'the poignancy of individual experiences' lending to the 'fraught history of the land'. ${ }^{14}$

Personal narrative certainly yields enjoyable vignettes to supplement tight analysis, but I think it has the potential to be more than this. Social history captures material that is not well dealt with by agricultural or economic or environmental history. It therefore deserves to be an intrinsic part of rural community analysis, and not just illustration. The trouble is, of course, that the kind of material that informs social history is more often anecdotal than comparable. This is great for providing colour, but it is difficult evidence to tabulate.

Peter Holland, nevertheless, continued to demonstrate how farm diaries can yield comparable data. Not only did he show how they could inform agricultural history, he also used them to advance weather history ${ }^{15}$ and to progress environmental history in general in his book Home in the Howling Wilderness. ${ }^{16}$

What I would love to see is further analysis of farm diaries that will enlighten us about the social history of New Zealand's rural areas, beyond both the agricultural and the environmental history. Chapter 7 of Peter's book, which concerned 'meetings, sales, competitions and exhibitions', is an indication of what might be possible in this direction.

In the 2018 symposium at which the first version of this paper was read, Peter provided a meticulous and pioneering analysis of stock and station agents' records, which showed how station supplies changed over the years and affected agricultural practice. ${ }^{17}$ Peter was in good form, delivering his findings with his usual clarity and enthusiasm. He died just a few weeks later, so this proved to be his final contribution to historical geography. It opens up the exciting prospect of future research, by other scholars, into another kind of archive that can shed light both on environmental and rural change.

The exceptional thing about Potts' early diary, which Peter never had the opportunity to study, is the frequency with which Potts breaks free of the station diary mould, and gives us so much more 'personal' material.

14 Abstract to Katie Cooper, 'Food and the transformation of rural New Zealand', paper delivered at 'Making Rural New Zealand: Environment, Economics and Politics' symposium, Dunedin, 2018.

15 P. G. Holland, P. Dixon and V. Wood, 'Learning about the weather in early colonial New Zealand', Weather and Climate 29 (2009): 3-21.

16 Peter Holland, Home in the Howling Wilderness: Settlers and the Environment in Southern New Zealand (Auckland: Auckland University Press, 2013). See also my review of this book in New Zealand Journal of History 47 , no. 2 (2013): 269-71.

17 Peter Holland, 'Stock and station agency records and rural landscape change', paper delivered at 'Making Rural New Zealand: Environment, Economics and Politics' symposium, Dunedin, 2018. 
The diary's owner at first only let me view it for a few hours and under a watchful eye. For a long time I only had my hastily scribbled extracts from Potts' diaries to refer back to, all of which I had chosen for their 'environmental' content. One example of this kind of extract relates to 12 October 1855 :

Set a Dorking hen on 15 eggs. Talking of eggs reminds me I ought to record the great number laid by the fowls here, quite surpassing my experience of their prolificacy in England ... Killed another weka this morning; it goes much against my inclination to wage exterminating war against these amusing and confident birds, but they are so partial to fowl's eggs and so persevering in their visits to the nesting places, that one is reduced to the alternatives of weka or eggs—we decide for the latter ... [Weka are] Good eating when stewed ... One that was tamed used to kill rats by securing them with its feet, and driving its wedge-like bill through its victim.

This is wonderful material for the environmental historian, since it shows not only the conflict of interest between a native species (the weka) and an introduced species (the hen), but also the ways in which both were adapting to changed circumstanceshens by laying more eggs, weka by learning to kill rats and eat hen's eggs. There was also adaptive behaviour on the part of the settler, who both added a new food to his diet, and tipped the scales in favour of the introduced by slaughtering the native species.

Since then, the owner of the Potts diary has sent me a complete copy. This means that I am now able to dwell on the rest of the material in it, which deals not with interactions between humans and their environment, but with interactions between humans and other humans.

One example of this was written by Potts, in a bad mood, on 2 October 1857, saying what he thought of the couple who help him and his wife with the farm and the children:

Jack and Maria ought to have the prize for dirt. I have to partake of the same food as they do, to share the same loaf, eat from the same dish, and anything more repulsive than their persons and habits I am at a loss to conceive; their squalid appearance from dirt and filth is disgusting. Jack never washes; I made him wash his hands today, which is an act I'm afraid he looks upon as arbitrary and tyrranical [sic], but as I have to cut my slice of bread off the loaf he uses, why, I hold myself excused under the circumstances. Maria rubs or washes her face and mouth and hair, and now and then disguises herself in a clean frock, but I suppose lest she should be accused of pride, suffers her neck, hands, arms and stockings to remain in status quo. Oh, for the largest engine of the London Fire Brigade [to hose them down].

This is far more vivid than what you find in most station diaries. Like the previous quotation, it concerns human adaptation (or the need for it) in a new environment, though here I am referring to a 'social' rather than a 'natural' environment. 
A stated intention of the New Zealand Company in 1847 had been 'to transplant English society with its various gradations in due proportions'. ${ }^{18}$ The reality in 1857 in Windwhistle, however, was an isolated rural community in which the demand for amenable or 'good' hired labour far outstripped its availability. Nor did rural Canterbury yet have the physical and social 'fences' that had so well separated and differentiated the classes in England. All parties had much to learn.

Another extract from Potts' diary also finds him in a bad mood, on 10 November 1855:

The job of milking is most disgusting from the extreme filthiness of the yards, and which the weather has precluded any attempt at improving. Literally up to the knees in thick sticky muck, and as several of the milkers [cows] don't condescend to enter the bails till they have been pursued round the yard half a dozen times with a long pole, their coyness is anathematised till every known curse is worn threadbare by constant repetition. What a contrast to old times at home [in England] where Charles, whose placidity was only equalled by his cows', went through his lactatory duties innocent of bails and leg-ropes and took the foaming buckets to the dairy almost as clean himself as his spotless pails; where the petted favourites, when you strolled about the garden, followed you with wistful eyes in hopes of a treat of cabbage leaves; here go to see the cattle and most likely at first sight of you they trot off, change the pace for a gallop and go perhaps two or three miles, only stopping when quite out of breath, leaving you, if on foot, ample time to reflect on England where 'The lowing herd winds slowly o'er the lea'. ${ }^{19}$

That last line is a quotation (slightly altered) from Thomas Gray's 'Elegy Written in a Country Churchyard'. The first few verses of this poem are a classic portrayal of the kind of English scene that Potts, as he remembered it, enjoyed while living in the Surrey countryside. It is what he wished to recreate in New Zealand in 1855, but it was not working. The weather was not English weather. There was no roofed milking shed. Potts' money still had not come through from England and he no longer had a skilled worker to do the milking for him. The skittish cows ran away and there was no fence to contain them. And there was not much of a garden yet, either.

The making of rural New Zealand as a whole breaks down into a thousand pictures of individual settlers, struggling with limited resources to transform unfamiliar landscapes. The pity is that there were so few rural settlers like Potts who both participated in and commented on rural change as it occurred. Herbert GuthrieSmith was a later settler who left an equally rewarding written record. ${ }^{20}$

18 Twenty-third Report of the Court of Directors of the New Zealand Company (London, 1847), 2.

19 T. H. Potts, diary, 10 November 1855.

20 Herbert Guthrie-Smith, Tutira: The Story of a New Zealand Sheep Station, 4th ed. (Seattle, WA: University of Washington Press, 1999). 
No doubt there were other observations from settlers in their letters 'home' to Britain, but few of these letters have survived. We are left with diaries, but also with thousands of columns of rural news and the like in regional newspapers. I suspect that these are the best of all remaining written primary sources, particularly since their digitisation has made them more accessible.

How can we best approach these various kinds of evidence? And, if I was researching the making of rural New Zealand, what would I expect to find? In historical research, it is often the case that you have some thoughts on your subject whether or not you want them, and the challenge then is to examine the evidence without prejudice.

One's prejudices are perhaps strongest when looking into a so-called planned settlement like Canterbury, when maybe most early British settlers came with no real plan at all, only with the hope that life would be better for them in a new place. Nevertheless, I posit a basic sequence of developments as things turned out for the minority who did actually live, as the Phillips and the Potts lived, in a rural rather than an urban context.

First, there was a rural ideal (and sometimes actual rural experience) that emigrants had 'in mind' when they left Britain for New Zealand. Second, they were confronted with a New Zealand reality that they sought to change and mould into an approximation of that ideal. Third, to some extent they succeeded in transforming the one into the other, and to some extent they failed. Fourth, in the course of this there came not only 'environmental learning' but also 'social learning' or 'social adjustment'. This resulted in a changed landscape, a changed way of life, different social interactions, and a pattern of rural settlement which had not been anticipated.

As emigrants became settlers, indigenous ecosystems became rural landscapes, primarily of managed pasture and scattered human settlements. Vision and substance continued to affect one another, and both were changed or adapted.

I suspect the language employed to describe rural settlement, and landscapes in general, will also have changed. A close look at individual examples of a word's use over time-examples of 'linguistic adjustment' - might be a way of gauging not only actual change in rural New Zealand, but also changes in perception. While an environmental historian could look at words like 'forest' and 'bush', a social historian could look at words like 'village' and 'township'.

A rural history of Canterbury settlement, then, might profitably examine not only the archival evidence in station diaries, stock and station records, newspapers, photographs and maps to clarify the actual sequence of perceptions, events and adaptations-it could also look specifically at a changing landscape of language, which will hint at changes in the social landscape as much as the natural landscape. 
But I am on uncertain ground here, presuming to reflect on research that has not been done-or at least not by me. Recording one day in 1856, Potts noted he had only 'managed to fork up a piece of ground, but perhaps it would have been better let alone'. I have felt much the same, as an environmental historian, straining to turn over evidence more as a rural historian would. I can only hope, as Potts did, that 'At any rate it will give it a sweetening. ${ }^{21}$ 
This text is taken from International Review of Environmental History, Volume 6, Issue 2, 2020, edited by James Beattie, published 2020 by ANU Press, The Australian National University, Canberra, Australia.

doi.org/10.22459/IREH.06.02.2020.06 